\title{
The Analysis of Protein Level and Amino Acid Profile in Eels (Anguilla marmorata (Q.) Gaimard and Anguilla bicolor) of Lake Poso
}

\author{
Jamaluddin*, Nur Atina and Yonelian Yuyun
}

Department of Pharmacy, Mathematics and Natural Science of Faculty, Tadulako University, Palu, Central Sulawesi, Indonesia

\begin{abstract}
In this study used a sample of eel fish species Anguilla marmorata (Q.) Gaimard and Anguilla bicolor from Poso lake that has a high protein content and is a fish endemic to Central Sulawesi. These eels are consumed by the surrounding community of the lake, but the nutritional content remains unknown. The present research was aimed to determine the protein level and amino acid profile of Anguilla marmorata (Q.) Gaimard and Anguilla bicolor eels. The protein level testing used Kjeldahl method, and amino acid profile used High Performance Liquid Chromatography. The results demonstrate the protein level of the two samples Anguilla marmorata (Q.) Gaimard eels have a protein content of 41.84\% and Anguilla bicoloreels at 33.75\%. Anguilla marmorata (Q.) Gaimard and Anguilla bicolor eels contain 18 types of amino acid, comprised of 9 types of essential amino acids and 9 types of non-essential amino acids. Of the two samples of eel species Anguilla marmorata (Q.) Gaimard and Anguilla bicolor, have complete protein quality because it has all kinds of essential amino acids.
\end{abstract}

Keywords: Amino acid, Anguilla bicolor, Anguilla marmorata, Protein.

\section{INTRODUCTION}

Indonesia has abundant diversityin fish species, including 8,500 and 1,300 species live in freshwater ecosystem [1]. One region in Indonesia with plenty of endemic freshwater fish species is Sulawesi. Endemic fish is fish species found in particular areas, such as rivers, lakes, islands, countries, and continents [2].

Central Sulawesi is a region with vast freshwater areas, one of which is Lake Poso. In general, there are several species of in Lake Poso, including eels (Anguilla sp). There are five (5) eel species found in Lake Poso, namely Anguilla marmorata (Q.), Gaimard, Anguilla celebensis, Anguilla interioris, Anguilla bicolor, dan Anguilla borneoensis [3]. Anguilla marmorata and Anguilla bicolor are the two species largely found and used as subsistence by the community living in banks of Lake Poso. This fish is very popular with the people due to their tastiness, and they are easy to find.

As food, fish is foodstuff with considerable protein level. The nutritional value of fresh fish consists of $17 \%$ protein, minerals and $2.5 \%$ to $4.5 \%$ vitamins. Fresh fish as protein source has advantages in comparison with protein sources from other materials; fish protein amino acid is particularly rich in lysine [4].

*Address correspondence to this author at the Department of Pharmacy, Mathematics and Natural Science of Faculty, Tadulako University, Palu, Central Sulawesi, Postal: 94118, Indonesia; Tel: +6281355198799;

E-mail: jamal_farmasi02@yahoo.co.id

ISSN: 2223-3806 / E-ISSN: 1927-5951/19
To date, there are no protein analysis publications or research results on the nutritional level of Anguilla marmorta and Anguilla bicolor eels from Lake Poso. The nutritional analysis of eels is highly needed, especially its protein level and its composition or amino acid profile. Based on these findings, there is a possibility of similar protein level between cultivated eels and Central Sulawasi's endemic eels. In order to prove the hypothesis, it is necessary to conduct analysis of protein level and amino acid profile in Anguilla marmorata and Anguilla bicolor eels from Lake Poso.

\section{MATERIALS AND METHODS}

\section{Materials}

Materials used in this research include: distilled water, sulfuric acid $\left(\mathrm{H}_{2} \mathrm{SO}_{4}\right)$ acid, boric acid $\left(\mathrm{H}_{3} \mathrm{BO}_{3}\right)$, penolptalin indicator, hydrochloric acid $(\mathrm{HCl}) 0.2 \mathrm{~N}$, sodium chloride $(\mathrm{NaCl})$, natruim hydroxide $(\mathrm{NaOH})$, AccQ-Fluor Borate, Kjeldhal tablets, Fluor Reagent A, and standard solution of amino acids.

\section{Methods}

\section{Samples Technique}

The samples used were from Lake Poso, sampling was carried out using purposive sampling method is a sample determination technique by choosing a sample among the population according to what the researcher wanted, ie based on the type of fish [5]. The types of

(c) 2019 SET Publisher 
samples taken were Eel fish Anguilla marmorata (Q.) Gaimard and Anguilla bicolor from Poso lake.

\section{Sample Preparation}

Sample preparation stage was begun with washing the sample using running water to clear the slime, and then the internal organs (viscera and gills) were rewashed. After the sample was cleaned, filleting stage began, where stainless steel knife was used to dissect them. The objective was to separate the bones from the flesh. The next process was weeding. It was done by pulling out the bones attached to the flesh. And the last stage was done by cutting off samples into small size and it was ready for analysis [6].

\section{Protein Analysis}

The sample was weighed by 0.5 grams and subsequently inserted into a $250 \mathrm{ml} \mathrm{Kjeldhal} \mathrm{flask.} \mathrm{The}$ destruction stage was performed by adding concentrated 1 gram of selenium and sulfuric acid $\left(\mathrm{H}_{2} \mathrm{SO}_{4}\right)$ of $12 \mathrm{ml}$ heated in smoker cabinet for 2 hours at $420^{\circ} \mathrm{C}$ until the color changed into a clear greenish solution. And then, destruction outcome was cooled off. The destruction outcome was then added with $50 \mathrm{ml}$ $\mathrm{NaOH}$ at $40 \%$, and $25 \mathrm{ml}$ aquadest, and was then distilled. Distillate was placed in a flask containing a mixture of $4 \% 10 \mathrm{ml}$ boric acid $\left(\mathrm{H}_{3} \mathrm{BO}_{3}\right)$ and 3 drops of phenolphthalein. Afterwards, titration was done by adding $\mathrm{HCl} 0.01 \mathrm{~N}$, little by little until it returned into a clear orange color. Determination of blank is where the treatment is the same as the sample, namely destructing, distilling and titrating. However, it differs in the use of only unsampled 1.2 grams of selenium.

Calculation:

$$
\% N=\frac{(m l \mathrm{HCl}-m l \text { Blank }) \times \text { Normality } \times 14,007 \times 100}{m g \text { of sample }}
$$

$\%$ protein: $\% \mathrm{~N} \times 6,25$

\section{Amino Acid Analysis}

\section{Sample Solution}

The sample is weighed at 0.1 grams and then added with $5 \mathrm{ml}$ of $6 \mathrm{~N} \mathrm{HCl}$, and was then vortexed and hydrolyzed for 22 hours at $110^{\circ} \mathrm{C}$ and cooled down. It was subsequently moved into $50 \mathrm{ml}$ volumetric flask and added with distilled water up to limit sign, filtered with $0.45 \mu \mathrm{m}$ filter, pipetted by $500 \mathrm{~mL}$, followed by 40 $\mathrm{mL}$ of a-amino- $N$-butyric acid (AABA), then added with approximately $460 \mathrm{~mL}$ of distilled water, pipetted with $10 \mu \mathrm{m}$ solution, added with $70 \mu \mathrm{L}$ AccQ-Fluor Borate, and then vortexed. Furthermore, $20 \mu \mathrm{L}$ reagent flour $\mathrm{A}$ was added and vortexed, and then was settled for 1 minute, incubated at $55^{\circ} \mathrm{C}$ for 10 minutes, and was injected on HPLC tool [7].

\section{Standard Solution}

Standard $40 \mu \mathrm{m}$ amino acid mix pipette was added with $40 \mu \mathrm{L}$ of internal standard a-amino-n-butyric acid (AABA), and then added with $920 \mu \mathrm{L}$ of distilled water after being homogenized. $10 \mathrm{~mL}$ standard was taken and was then added with $70 \mu \mathrm{L}$ AccQ-Fluor Borate and was then vortexed. Furthermore, $20 \mu \mathrm{L}$ reagent flour $\mathrm{A}$ was added, vortexed, and then added for 1 minute. Afterwards, it was incubated at $55^{\circ} \mathrm{C}$ for 10 minutes and was then injected to HPLC instrument.

Calculation:

Rationality of sampelx (C.standard $\left.\frac{\text { pmol }}{1000000000}\right) \times B M x f p x 1000$ Rationality standard $x$ sample weight $(g)$

Amino acid level $(\mathrm{mg} / \mathrm{g})$ = amino acid level $(\mathrm{mg} / \mathrm{kg}) /$ 1000

Tryptophan level $(\mathrm{mg} / \mathrm{kg})=$ (area-intercept) $x \mathrm{fp} /$ (slope $\mathrm{x}$ sample weight)

\section{RESULTS}

The result of ananlysis of amino acid profile and eel protein content of Anguilla marmorata (Q.) Gaimard and Anguilla bicolor are presented in Graphic images 1,2 , and 3.

\section{DISCUSSIONS}

The present research was conducted to analyze the nutrient level, i.e. the protein level and amino acid profile of Anguilla marmorata (Q.) Gaimard and Anguilla bicolor eels, becoming the information on the fish's nutritional value which is also endemic fish of Central Sulawesi. Anguilla marmorata (Q.) Gaimard eels have a yellowish skin and black spots, whilst Anguilla bicolor has dark skin. This research conducted analysis of protein level and amino acid profile.

The research was conducted to analyze the nutritional content, namely the protein level and amino acid profile of Anguilla marmorata (Q.) Gaimard and Anguilla bicolor eels, thereby becoming information on the fish's nutritional value which is also an endemic fish of Central Sulawesi. Anguilla marmorata (Q.) Gaimard eels have a yellowish skin and black spots, whilst 


\section{Analysis Result on Amino Acid Level of Anguilla marmorata (Q.) Gaimard}

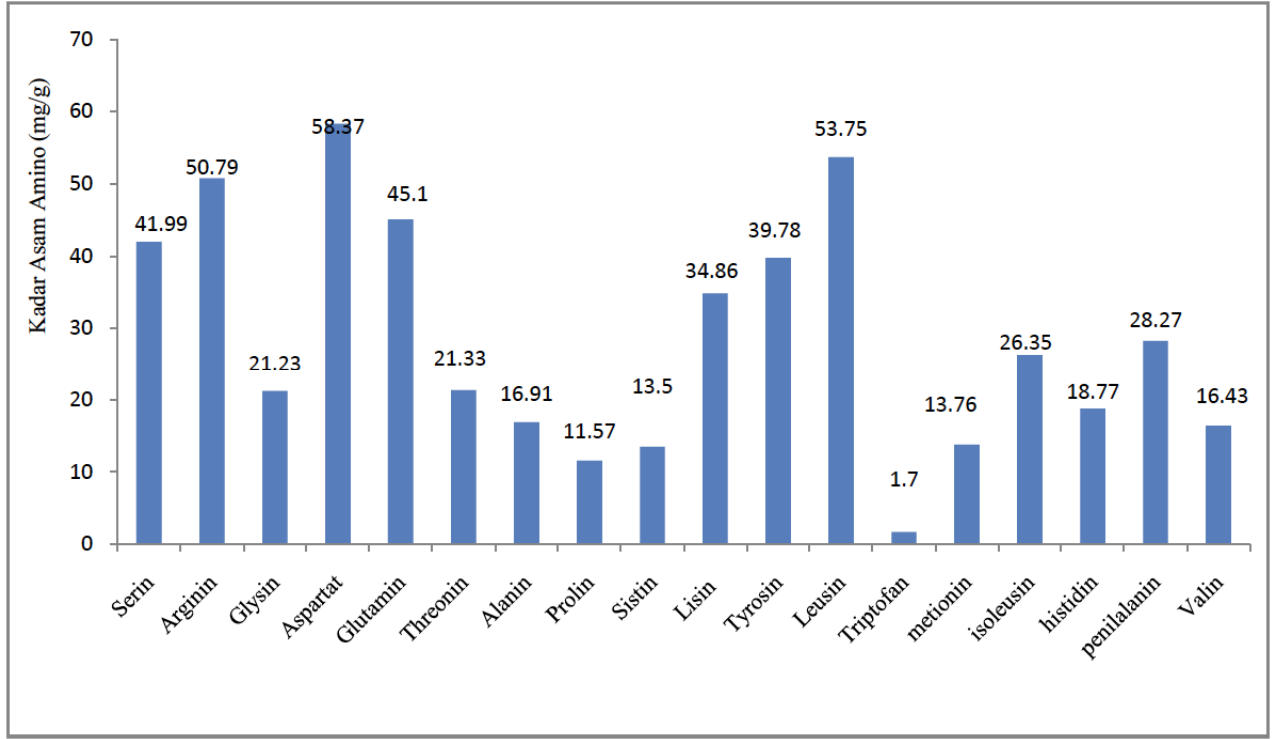

Graph 1: Amino Acid Level of Anguilla marmorata (Q.) Gaimard.

\section{Analysis Result on Amino Acid Level of Anguilla bicolor}

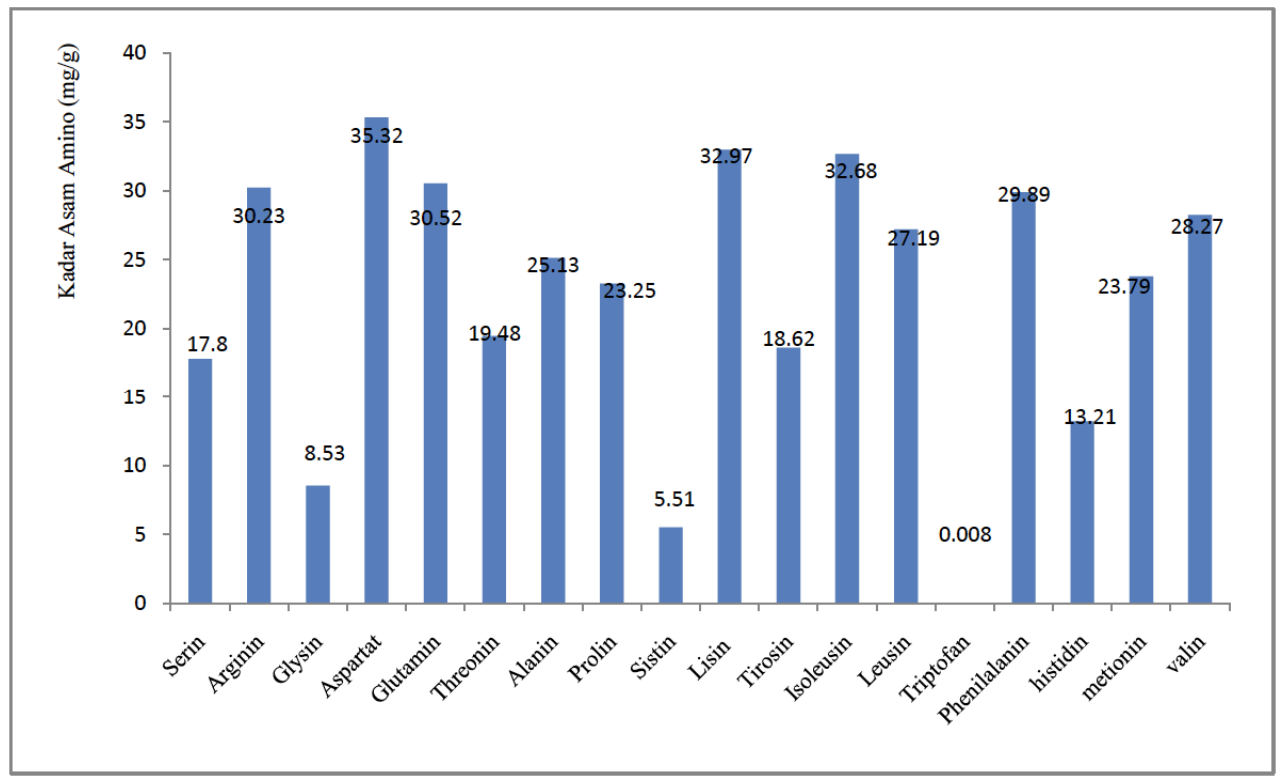

Graph 2: Amino Acid Level of Anguilla bicolor.

Anguilla bicolor has dark skin. This research conducted analysis of protein level and amino acid profile.

In the protein analysis stage in eels, Kjedhal method was used. The determination using Kjedhal method was performed by volumetric analysis with titration technique. The measurement principle of nitrogen content in food with Kejedhal method is the oxidation of organic compounds by sulfuric acid into carbon dioxide, water and nitrogen. Nitrogen compounds are released in the form of ammonia (ammonium sulfate), meanwhile carbon dioxide and water are separated by distillation process. Ammonia reacts with excess acid, forming ammonium sulfate. The solution is made alkaline, and the ammonia is evaporated and absorbed in boric acid solution. The nitrogen in the solution is determined by acid titration of $\mathrm{HCl} 0.1 \mathrm{~N}$. The total protein level is the amount of grams of protein in food, i.e. the amount of grams multiplied by a conversion factor of 6.25 , based on the assumption that the protein contains 16 percent of nitrogen. 


\section{Protein Analysis}

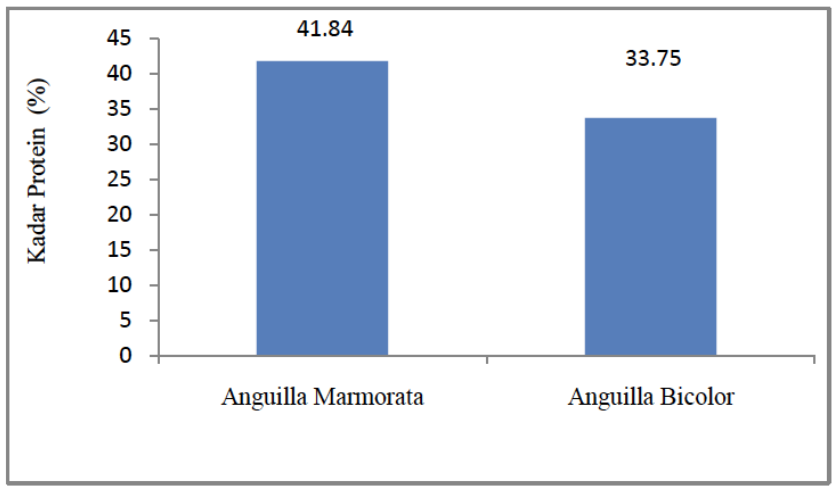

Graph 3: Protein Level.

The analysis results on proteins found in Anguilla marmorata (Q.) Gaimard and Anguilla bicolor eels can be seen in Graph 3 as the result of proteins analysis histogram. The results demonstrate that the protein level of both species of Central Sulawesi Anguilla marmorata (Q.) Gaimard and Anguilla bicolor are different. Anguilla marmorata (Q.) Gaimard contains protein of 41.84 (\%) and Anguilla bicolor of $33.75(\%)$. The total content owned by eels differs from the research [8], stating that the content of Anguilla bicolor eels is 30.50 (\%). This difference is caused by several factors, such as habitat, age, and the food digested [9]. The protein level in the body functions as the builder and maintenance. High level of protein shows utilization opportunity as one source of animal protein, where the value of the protein in Anguilla marmorata (Q.) Gaimard and Anguila bicolor eels is included high quality or perfect protein.

Organic compounds serve as a component of protein are amino acids. Amino acid analysis was performed using High Performance Liquid Chromatography (HPLC). The column on HPLC tool used is ACCQ-Tag Ultra $\mathrm{C}_{18}$ so that the reagents used are in the form of ACCQ-Tag Fluor Borate which is aimed to produce free amino acids. The detector used is PDA detector (Photodiode Array) with a wavelength of $260 \mathrm{~nm}$. It can be interpreted that the detector emits at wavelength of $260 \mathrm{~nm}$ and captures fluorescence emitted by the sample. Therefore, KCKT method is appropriate HPLC method to be used for non-volatile compounds, stable and not thermally.

Amino acids are usually soluble in water and insoluble in non-polar organic solvents, such as ether, acetone, and chloroform [10], as based on their chemical properties, amino acid is a weak base; therefore hydrolysis is performed first, which is aimed to produce free amino acid [9].
Internal standard solution or AABA (a-amino- $N$ butyric acid) is used for correcting factor in volumetric error during sample preparation and correcting the loss of amino acid residues during the hydrolysis process that will be detected by reduction in internal standard; hence the use of internal standard solution can improve precision. Amino acid is derivatized first to form derivatives that are able to fluoresce for altering the molecular structure or analyte polarity so as to produce a better chromatogram peak.

Anguilla marmorata (Q.) Gaimard and Anguilla bicolor eels have considerably complete amino acid profile and consist of 9 types of essential amino acids and 9 types of non-essential amino acids. When added together, there are 18 types of amino acids as protein constituents. Anguilla marmorata (Q.) Gaimard contains essential amino acid. There are 9 essential amino acids in the level. The result can be seen in Graph 2 from histogram result of amino acids. Thereby, Anguilla marmorata (Q.) Gaimard eels have considerable essential amino acids compared with Nila fish studied with only 8 essential amino acids. Leucine has the highest level, found in Anguilla marmorata (Q.) Gaimard eels at $53.75 \mathrm{mg} / \mathrm{g}$, leucine serves to stimulate brain function, increases energy levels of muscle, and helps bone healing. Leucine also has function in maintaining the immune system [11].

From the analysis of Anguilla marmorata (Q.) Gaimard eels, they have 9 different types of nonessential amino acids. The level of essential amino acid can be seen in Graph 2 Chromatogram Results of Amino Acid Analysis. Therefore, Anguilla marmorata (Q.) Gaimard has considerably complete non-essential amino acid compared with tilapia studied with only 6 types of non-essential amino acids. Aspartic acid is the highest type of amino acids with a total $58.37 \mathrm{mg} / \mathrm{g}$. Aspartic acid is a component playing a role in the biosynthesis of urea, precursor pyrimidine. In addition, aspartic acid is useful for the treatment of chronic fatigue and increased energy [12].

Meanwhile, Anguilla bicolor eels contain 10 essential amino acids. The level of it can be seen in Graph 2. Chromatogram Results of Amino Acid Analysis. Therefore, Anguilla bicolor eels have considerably complete essential amino acids compared with tilapia studied with only 9 types of essential amino acids. Tyrosine has the highest level, as found in Anguilla bicolor eels, equals to $39.78 \mathrm{mg} / \mathrm{g}$. Tyrosine has several benefits that can reduce stress, antidepressant, and drug and cocaine detoxification [12]. From the analysis of Anguilla bicolor eels, they have 9 
different types of non-essential amino acids. The essential amino acid level can be seen in Graph 2. Chromatogram Results of Amino Acid Analysis. Thereby, Anguilla bicolor eels have has a non-essential amino acid that is considerably complete, compared with tilapia studied with only 6 types of non-essential amino acids. Aspartic acid is highest type of amino acid playing a role in urea biosynthesis, a pyrimidine precursor. Besides, aspartic acid is useful for the treatment of chronic fatigue and increased energy [12].

Study conducted on major nutrition in four eel fish aquaculture from Namwon, South Korea ie (Anguilla japonica, Anguilla rostrata, Anguilla bicolor and Anguilla marmorata), with the Kjedahl and HPLC methods founded a total protein total in Anguilla marmorata (17,7\%), Anguilla bicolor (17,4\%), Anguilla rostrata (16,3\%), and Anguilla japonica (15,8\%). The Amino acid profiles result obtained 15 types of amino acids, where in the four species the highest amino acid content was glutamic acid respectively $(2.44 \%, 2.5 \%$, $2.39 \%$, and $2.23 \%$ ) and the lowest was tyrosine respectively $(0.54 \%, 0.57 \%, 0.51 \%$, and $0.52 \%)$ [13].

Another study on the comparison of the fatty acid profile of eel fish (Anguilla marmorata (Q.) Gaimard) in the yellow eel from Palu River and Poso Lake using the gas chromatography method. The result of fatty acid analysis of eel from Palu River and Poso Lake showed saturated fatty acid content of $2.766 \mathrm{~g} / 100 \mathrm{~g}$ and 0.275 $\mathrm{g} / 100 \mathrm{~g}$; monounsaturated fatty acids of $4.029 \mathrm{~g} / 100 \mathrm{~g}$ and $0.276 \mathrm{~g} / 100 \mathrm{~g}$; and polyunsaturated fatty acids of $0.541 \mathrm{~g} / 100 \mathrm{~g}$ and $0.102 \mathrm{~g} / 100 \mathrm{~g}$, respectively. The fatty acid compositions of yellow eel meat from Palu River are 23 species and from Poso Lake are 18 species. The fatty acid composition in yellow eel meat from Palu River and not found in Lake Poso are Cis11,14,17-eicosatrienoic, gamma-linoleic acid, myristoleic acid, Cis -10-pentadecenoate, and heneicosanoic acid [14].

It is known that eel fish have a complete amino acid composition, nearly similar with amino acid composition of other freshwater fish. From the amino acid composition, a calculation is done to chemical score. The calculation result shows the essential amino acid level in Anguilla marmorata (Q.) Gaimard eels have the highest chemistry score, at $77.87 \mathrm{mg} / \mathrm{g}$. And in bicolor eels, the highest chemical score is isoleucine at 81.75 $\mathrm{mg} / \mathrm{g}$. According Acton dan Rudd (1987), fish meat has a chemical score between $57-85 \mathrm{mg} / \mathrm{g}$. From the research, it can be seen that the chemical score of fish vary based on species, age, anatomy, type of food, and geographical location.
The highest chemical score is chicken eggs, i.e. 100. Therefore they are used as referal protein. From Graph 1, it can be seen that in Anguilla marmorata (Q.) Gaimard eels, tryptophan amino acid chemical score is at the lowest, at $1.7 \mathrm{mg} / \mathrm{g}$, below the standard protein at $10 \mathrm{mg} / \mathrm{g}$. It shows that the amino acid of tryptophan is a borderline amino acid in Anguilla marmorata (Q.) Gaimard eels. And in bicolor eels, the lowest chemical score of tryptophan amino acid is $0.08 \mathrm{mg} / \mathrm{g}$ of protein, below the standard protein at $10 \mathrm{mg} / \mathrm{g}$, which is also a borderline amino acid.

The amino acid level in fish is not the same. Each species has varying physiological processes. It also distinguishes the nutritional content of each fish species [15].

\section{CONCLUSION}

Of the two samples of eel species Anguilla marmorata (Q.) Gaimard and Anguilla bicolor, have complete protein quality because it has all kinds of essential amino acids. The protein content of Anguilla marmorata (Q.) Gaimard species is $41.48 \%$ and Anguilla bicolor is $33.75 \%$. While the result of amino acid profile analysis from both samples of fish obtained 18 types of protein amino acid composed of 9 types of essential amino acids in Anguilla marmorata (Q.) Gaimard species (leucine $53.75 \mathrm{mg} / \mathrm{g}$, lysine 34.86 $\mathrm{mg} / \mathrm{g}$, cystine $13,50 \mathrm{mg} / \mathrm{g}$, tyrosine $39,78 \mathrm{mg} / \mathrm{g}$, threonin $21,33 \mathrm{mg} / \mathrm{g}$, valine $16,43 \mathrm{mg} / \mathrm{g}$, tryptophan 1,7 $\mathrm{mg} / \mathrm{g}$, isoleucine $26,35 \mathrm{mg} / \mathrm{g}$, phenylalanine 28,27 $\mathrm{mg} / \mathrm{g}$ ), Anguilla bicolor species (isoleucine $32.68 \mathrm{mg} / \mathrm{g}$, leucine $27.19 \mathrm{mg} / \mathrm{g}$, lysine $32.97 \mathrm{mg} / \mathrm{g}$, cystine 5.1 $\mathrm{mg} / \mathrm{g}$, phenylalanine $29.89 \mathrm{mg} / \mathrm{g}$, tyrosine $18,62 \mathrm{mg} / \mathrm{g}$, threonine $19.48 \mathrm{mg} / \mathrm{g}$, tryptophan $0.08 \mathrm{mg} / \mathrm{g}$, valine $28.27 \mathrm{mg} / \mathrm{g}$ ) and 9 types of non-essential amino acids in Anguilla marmorata (Q.) Gaimard species (glycine $21.23 \mathrm{mg} / \mathrm{g}$, Glutamine $45,10 \mathrm{mg} / \mathrm{g}$, serine $41,99 \mathrm{mg} / \mathrm{g}$, alanine $16,91 \mathrm{mg} / \mathrm{g}$, arginine $50,79 \mathrm{mg} / \mathrm{g}$, proline 11,57 $\mathrm{mg} / \mathrm{g}$, histidine $18,77 \mathrm{mg} / \mathrm{g}$, metionin $13,76 \mathrm{mg} / \mathrm{g}$, aspartic acid $58.37 \mathrm{mg} / \mathrm{g}$ ), Anguilla bicolor species (glycine $8,53 \mathrm{mg} / \mathrm{g}$, glutamine $30,52 \mathrm{mg} / \mathrm{g}$, serine 17,80 $\mathrm{mg} / \mathrm{g}$, alanine $25,13 \mathrm{mg} / \mathrm{g}$, arginine $30,23 \mathrm{mg} / \mathrm{g}$, proline $23,25 \mathrm{mg} / \mathrm{g}$, histidine $13,21 \mathrm{mg} / \mathrm{g}$, methionine 23.79 $\mathrm{mg} / \mathrm{g}$, aspartic acid $35.32 \mathrm{mg} / \mathrm{g}$ ).

\section{ACKNOWLEDGEMENT}

The authors thank to PT. Saraswanti Indo Genetech (SIG), Bogor, Indonesia for analysis of protein level and amino acid profile. 


\section{REFERENCES}

[1] Budiman A, Arief AJ, Tjakrawidjaya AH. The Role of Zoological Museums in Research and Conservation of Biodiversity (fish). Bogor: Research Center for Biology Indonesian Institute of Sciences (LIPI): 2002.

[2] Sunarya W. Endangered Sumatra Endemic Fish. Depok: Islamic University: 2002.

[3] Anonymous. Rich Opportunities with Eel Cultivation, http://selayarvet.blogspot.com/2010/peluang-kaya-denganbudidayat-sidat.html, Accessed on 7 January 2016, 23.30 WITA: 2010.

[4] Munifah, Ayu Hapsari, R, Morina Tarihoran Y. Basic Culinary Nutrition. Palangkaraya: Graha IImu: 2014.

[5] Handayani KI. Effect of Boiling Media on Mineral Composition of Meth Freshwater Shellfish (Batissa violacea L, 1818) 2016; 1(1): 31-31.

[6] Hastarini E, Fardiaz D, Irianto HE, Budijanto S. Characteristics of Fish Oil from Filet Processing Waste of Siamese Patin Fish (Pangasius hypopthalamus) and Patin Jambal (Pangasius djambal). Ciampea 2012; 32(4): 404.

[7] Jamaluddin, Mappiratu, Septiawan, and Yuyun Y. Analysis of Fatty Acid and Amino Acid Profile of "Meti" Mussels (Batissa violacea L. von Lamarck, 1818) In La'a River of Petasia District North Morowali Regency. Rasayan Journal of Chemistry 2016; 9(4): $673-679$
[8] Widyasari RA, Hangesti Emi, Clara M Kusharto, Budy Wiryawan Eko Sri Wiyono, and Sugeng Heri Suseno. Fish Waste Utilization of Indonesian eel fish (Anguilla bicolor) For Flour In Processing Industry In Pelabuhan Ratu Sukabumi. Nutrition and Food Journal 2013; 8(3): 215-220.

[9] Winarno FG. Food C hemistry And Nutrition. PT. Gramedia Pustaka Tama. Jakarta: 2008.

[10] Sitompul S. Analysis of Amino Acids in Fish Flour and Donkey Meal. Agricultural Engineering Bulletin 2004; 9(1): 33-37.

[11] Edison T. Amino Acid: Esensial for Our Bodies. http://livewellnaturally.com [1 March 20016]: 2009.

[12] Linder MC. Biochemistry of Nutrition and Metebolism by Chemical Uses. Jakarta: UI Press: 1992.

[13] Cheul JA, et al. An Evaluation of Major Nutrients of Four Farmed Freshwater Eel Fish Species (Anguilla japonica, $A$. rostrata, A. bicolorand A. marmorata). Kor J Fish Aquat Sci 2015; 48(1): 044-050.

[14] Jamaluddin J, Amelia P, Widodo A. Studi Perbandingan Komposisi Asam Lemak Daging Ikan Sidat (Anguilla marmorata (Q.) Gaimard) Fase Yellow Eel Dari Sungai Palu Dan Danau Poso. Jurnal Farmasi Galenika 2018; 4(1): 73-78.

[15] Okuzumi M, Fujji T. Nutrional and Functional Properties Of Aquid and Cuttlefish. Japan: National Cooperative Assiciation Of Processors: 2000. 